addressing reports to each practice in this multipractice health centre rather than the overall practice manager of the health centre.

(b) Within the hospital the laboratory policy is to return reports to the specimen sourcefor example, ward, outpatients department, etc. Occasionally a request is made on the form to return the report to a different destination, such as consultant secretary, ward rather than outpatients departments, etc. This might improve efficiency in the eyes of the ward staff, but we identified examples of missing reports which increased the turnround time. These problems are now overcome by sending a normal report to the source and a duplicate report to the requested destination.

It is intended to reapply the method in the future as part of our ongoing audit activity to close the audit loop and ensure that improvements in quality have been made and maintained. It is also intended to use the telephone contacts for other uses, such as user satisfaction survey.

1 Rogers S, Bywater MJ, Reeves DS. Audit of turn-around times in a microbiology laboratory. $f$ Clin Pathol 1991;44:257-8.

2 Homanitz PJ, Steindel SJ. Interlaboratory performance and laboratorians' expectations for stat turnaround times. Arch Pathol Lab Med 1991;115:977-83.

3 Moss F, Smith R. From audit to quality and beyond. $\mathrm{Br}$ Med f 1991;303:199-220.

\title{
Evaluation of modified passive haemagglutination assay for Vi antibody estimation in Salmonella typhi infections
}

\author{
G Kang, G Sridharan, M V Jesudason, T J John
}

\begin{abstract}
A simple passive haemmagglutination assay (PHA) was developed to detect Vi antibodies, to improve the diagnosis of typhoid fever by small laboratories. The Vi capsular antigen of Salmonella typhi was extracted by alternate alcohol and acetone precipitation. Formalin fixed, sheep red blood cells treated with chromium chloride were sensitised with this $V i$ antigen and antibodies detected and measured by PHA. The test had a sensitivity of $83.3 \%$ among 30 cases of typhoid fever confirmed by culture. The specificity of the test was $94 \%$, making it suitable for use in laboratories without facilities for IFAT or ELISA.
\end{abstract}

Typhoid fever continues to be a major problem in tropical developing countries. The facilities available for a confirmative microbiological diagnosis are often inadequate in such areas. Simple, economical, and reliable methods for diagnosis are therefore imperative. The conventional Widal test serves a useful but modest purpose. Many immunological tests such as indirect fluorescence antibody test (IFAT) and enzyme linked immunosorbent assay (ELISA) have been devised to detect $\mathrm{Vi}$ antibody in the serum of patients with typhoid fever and typhoid carriers. ${ }^{12}$ The passive haemagglutination assays (PHA) have been used for antibody detection in typhoid carriers. ${ }^{3}$ Those reported have relied on heat extracted $\mathrm{Vi}$ antigen or antigen prepared by ethanol-cetavlon precipitation. ${ }^{4}$ This report describes a modified method of $\mathrm{Vi}$ antigen preparation and evalu- ation of the PHA both in cases of typhoid fever and typhoid carriers.

\section{Methods}

Vi antigen was prepared from $S$ typhi (ST) (NCTC 8382) grown on Mueller Hinton agar for 18 hours. The saline harvest of the organisms was heated at $100^{\circ} \mathrm{C}$ for one hour and centrifuged. The supernatant was treated with 2.5 volumes of absolute ethanol and proteins precipitated out. Centrifuged supernatant was treated with 3 volumes of acetone and the $\mathrm{Vi}$ polysaccharide was precipitated out and vacuum dried. Sheep red blood cells (SRBC) were fixed in formalin according to Csizmas's method. ${ }^{5}$ Formalin $(50 \mathrm{ml})$ was dialysed into $200 \mathrm{ml} \mathrm{12.5 \%} \mathrm{(SRBC)} \mathrm{in} \mathrm{phosphate} \mathrm{buffered}$ saline ( $\mathrm{pH} \mathrm{7.4)}(0.13 \mathrm{M})$ (PBS) for three hours and then formalin released into the SRBC suspension. This mixture was placed on a rotator overnight at room temperature. The coarse particles were removed and the SRBC suspension washed and stored at $4^{\circ} \mathrm{C}$. A $4 \%$ suspension of SRBC was treated with chromium chloride $\left(\mathrm{CrCl}_{3}, 6 \mathrm{H}_{2} \mathrm{O}\right)$ at a concentration of $40 \mu \mathrm{g} / \mathrm{ml}$ for 15 minutes at $37^{\circ} \mathrm{C}$ with frequent mixing. After three washes in PBS, $\mathrm{pH} 7.4(0.15 \mathrm{M}), 2 \mathrm{ml}$ of a $10 \%$ suspension of treated cells were mixed with $1 \mathrm{ml}$ of $\mathrm{Vi}$ antigen solution $(2 \mathrm{mg} / \mathrm{ml})$ and incubated at $37^{\circ} \mathrm{C}$ for two hours with continuous mixing. The cells sensitised with $\mathrm{Vi}$ antigen were made

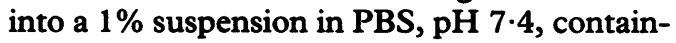
ing $0.2 \%$ bovine serum albumin (BSA). A $1 \%$ suspension of unsensitised cells treated with chromium chloride was also prepared to serve as controls. All sera were absorbed with SRBC 
Comparison of tube agglutination test (TA) and passive haemagglutination assay (PHA) for Vi antibody

\begin{tabular}{|c|c|c|c|c|c|c|c|}
\hline \multirow[b]{2}{*}{ Group } & \multirow[b]{2}{*}{$\begin{array}{l}\text { Number } \\
\text { tested }\end{array}$} & \multicolumn{3}{|l|}{$V i T A$} & \multicolumn{3}{|l|}{$V i P H A$} \\
\hline & & $\begin{array}{l}\text { Range of } \\
\text { titres }\end{array}$ & $\begin{array}{l}\text { Geometric } \\
\text { mean titre }\end{array}$ & $\begin{array}{l}\text { Number (\%) } \\
\text { positive }\end{array}$ & $\begin{array}{l}\text { Range of } \\
\text { titres }\end{array}$ & $\begin{array}{l}\text { Geometric } \\
\text { mean titre }\end{array}$ & $\begin{array}{l}\text { Number (\%) } \\
\text { positive }\end{array}$ \\
\hline $\begin{array}{l}\text { Healthy controls } \\
\text { Suspected connective tissue } \\
\text { disorders }\end{array}$ & $\begin{array}{r}100 \\
20\end{array}$ & $\begin{array}{l}\leqslant 20-80 \\
<20\end{array}$ & $\begin{array}{c}26 \cdot 4 \\
0\end{array}$ & $\begin{array}{l}2 \\
0\end{array}$ & $\begin{array}{l}\leqslant 40-160 \\
\leqslant 40-160\end{array}$ & $\begin{array}{l}56 \cdot 3 \\
66 \cdot 0\end{array}$ & $\begin{array}{ll}6 & (6 \cdot 0) \\
1 & (5 \cdot 0)\end{array}$ \\
\hline $\begin{array}{l}\text { Non typhoid fever }(B C+W \\
\text { negative) }\end{array}$ & 29 & $\leqslant 20-80$ & $40 \cdot 0$ & $4(13 \cdot 8)$ & $\leqslant 40-320$ & $46 \cdot 8$ & $6(20 \cdot 7)$ \\
\hline $\begin{array}{l}\text { Presumptive typhoid fever } \\
\text { (W positive) }\end{array}$ & 80 & $\leqslant 20-320$ & $67 \cdot 8$ & $36(45 \cdot 0)$ & $\leqslant 40-640$ & $116 \cdot 3$ & $56(70 \cdot 0)$ \\
\hline $\begin{array}{l}\text { Confirmed typhoid fever } \\
\text { (BC positive) }\end{array}$ & 30 & $\leqslant 20-160$ & 48.9 & $10(33 \cdot 3)$ & $\leqslant 40-640$ & $195 \cdot 0$ & $25(83 \cdot 3)$ \\
\hline
\end{tabular}

W Widal test; BC Blood culture

(1 volume packed SRBC: 10 volumes in 10 serum dilution) at $37^{\circ} \mathrm{C}$ for 30 minutes. This was to remove heterophile haemagglutinins. The SRBC absorbed sera were diluted in doubling dilutions ranging from 1 in 20 to 1 in 640 in microtitre plates in $0.025 \mathrm{ml}$ volumes. Sensitised SRBC $(0.025 \mathrm{ml})$ were added to each serum dilution and the first serum dilution was screened with $1 \%$ unsensitised cells. The PHA test gave a titre of 5120 with rabbit anti-Vi but was negative with both rabbit antiSTO and anti-STH, establishing its specificity for Vi antibody. The sensitised cells (PHA reagent) remained stable for up to two weeks at $4^{\circ} \mathrm{C}$. The sera were also tested in a tube agglutination test carried out with formalin fixed $\mathrm{Vi}$ positive $S$ typhi cells and in the conventional Widal test. A total of 259 coded sera were tested. This included sera from 30 patients with typhoid fever, confirmed by positive blood culture, 80 presumptive typhoid fever patients in whom the Widal test was diagnostic (anti-STO, anti-STH $\geqslant 160$ ), 29 non-typhoidal febrile patients, 20 patients with connective tissue disorders and 100 healthy controls. Paired sera were collected before and after vaccination against typhoid fever from five volunteers. The group with connective tissue disorders was included to preclude false positive results in PHA due to rheumatoid factor or circulating immune complexes.

\section{Results and discussion}

Among the 100 healthy controls a geometric mean titre of 26.4 was observed in the tube agglutination test and 56.3 in the PHA Vi antibody test. The cutoff was 80 for tube agglutination and 160 for PHA. Of 30 confirmed typhoid fever patients, PHA was positive in $25(83.3 \%)$ and tube agglutination in $10(33.3 \%)$. Of 80 presumptive typhoid fever patients, $56(70 \%)$ had PHA titres of 160 or more; only $36(45.0 \%)$ had tube agglutination titres of 80 or more. Using positive blood cultures as the "gold standard" for diagnosing typhoid fever and healthy controls as disease negative, the PHA had a sensitivity of $83.3 \%$ and a specificity of $94 \%$ for diagnosing typhoid fever. The PHA did not give an increased false positivity among patients with non-typhoid febrile illness or connective tissue disorders. The results are shown in the table. The PHA test also detected Vi antibody in seven of 10 (70\%) typhoid carriers.

Of the five volunteers whose antibody titres were measured before and four weeks after vaccination against typhoid fever, all five showed a fourfold or greater rise in titre of antibodies to STH, two to STO, and none to ST Vi antigen. Among our study population the Widal test was positive in only $56 \%$ of blood culture positive patients; the PHA for Vi antibody estimation was positive in $83.3 \%$. The PHA for Vi antibody detection therefore seems to be a good test for typhoid fever in small laboratories where culture facilities are not adequate or facilities for IFAT and ELISA are not available.

This work was carried out as part of a project funded by the Department of Biotechnology, Government of India, under the Indo-US Vaccine Action Programme, Grant No BT/ 10/023/VAP/CMC-P23/88.

1 Doshi N, Taylor AG. Comparison of the Vi fluorescent antibody test with the Widal agglutination method in the serodiagnosis of typhoid fever. $¥$ Clin Pathol 1984;37: 805-8.

2 Barrett TJ, Blake PA, Brown SL, et al. Enzyme-linked immunosorbent assay for detection of human antibodies to Salmonella typhi Vi antigen. $f$ Clin Microbiol 1983; 17:625-7.

3 Lanata CF, Ristori C, Jiminez L, et al. Vi serology in detection of chronic Salmonella typhi carriers in an endemic area. Lancet 1983;ii:441-3.

4 Wong $\mathrm{KH}$, Feeley JC. Isolation of the $\mathrm{Vi}$ antigen and a simple method for its measurement. Appl Microbiol 1972;24:628-63.

5 Csizmas L. Preparation of formalinized erythrocytes. Proc Soc Exp Biol Med 1960;103:157-60. 